\title{
Understanding the Therapeutic Potential of Bone Marrow Stem Cell Therapy in Ischemic Stroke
}

\author{
Austin B. Carpenter ${ }^{1}$, Hana Ahsan ${ }^{2}$, Adrian Kong ${ }^{2}$, Anup Regunathan ${ }^{2}$ \\ ${ }^{1}$ Medicine, Georgetown University (DC), 2 Physiology, Georgetown University (DC) \\ Keywords: ischemic stroke, stem cells, bone marrow \\ https://doi.org/10.52504/001c.3417
}

Georgetown Medical Review

Vol. 2, Issue 1, 2018

\begin{abstract}
Despite advances in clinical management, ischemic stroke remains one of the most significant causes of morbidity and mortality in the United States. Stem cell transplantation therapy is emerging as a promising solution to this problem. Ischemic stroke leads to the death of neurons and the surrounding glial cells, leaving patients with significant disabilities. Stem cell therapy has been proven effective in several preclinical studies of induced ischemic stroke, demonstrating neurogenesis, angiogenesis, and improved neural plasticity in animal models. Bone marrow-derived stem cells have shown particular promise in this regard, leading to their application in clinical trials that demonstrated safety and feasibility with limited efficacy. Here, we highlight the potential benefits of cell transplantation therapy for ischemic stroke and review potential mechanisms of action and delivery. We also examine the results of completed clinical trials and the scientific roadblocks that have prevented them from demonstrating greater efficacy. While progress in the clinic has been limited, the future of stem cell therapy is promising. There is still debate as to the methods and applications that would most improve the efficacy of stem cell therapy for ischemic stroke and we review proposed solutions that would address these issues and improve therapeutic designs for future studies.
\end{abstract}

\section{INTRODUCTION}

Stroke is a leading cause of morbidity and mortality in the United States. Since 2000, approximately 795,000 strokes have occurred per year in the United States, causing approximately 1 of every 19 deaths ${ }^{1}$. Of those, 610,000 were first events and 185,000 were recurrent strokes ${ }^{1}$. There are 2 types of stroke: ischemic, due to lack of blood flow, and hemorrhagic, due to bleeding from a ruptured or weakened blood vessel. Here, we focus on ischemic stroke, which accounts for $87 \%$ of the total incidents ${ }^{2}$. Although overall stroke mortality has declined over the past decade, morbidities from stroke remain significant and debilitating ${ }^{1}$. This is partially because tissue plasminogen activator $(\mathrm{tPA})$ is currently the only approved treatment for acute ischemic stroke ${ }^{3}$. tPA thrombolytic therapy has a relatively short time frame ( 4.5 hours) in which it can be administered after an ischemic event ${ }^{3}$. This leaves less than $5 \%$ of patients able to receive therapy within that narrow window and many others with significant disabilities ${ }^{4}$. While tPA administration has been shown to be effective at improving clinical outcome, some patients who do receive this thrombolytic therapy still have meaningful disability at 90 days after treatment 3,5 . Thus, it is clinically urgent to not only extend the limited window of time, but also to improve care and clinical outcome. Because one of the primary effects of ischemic stroke is cell death, regenerative therapy using stem cells has recently emerged as a promising option to treat not only the symptoms, but 
also the underlying damaged brain tissue through their self-renewal capacity, differentiation ability, and interaction with the local host microenvironment 6,7. Additionally, it is proposed that stem cell transplantation could extend the possibilities for therapy beyond the 4.5-hour limit required for tPA ${ }^{6}$. Numerous approaches have been tested to investigate the most feasible and efficacious system, but bone marrow-derived stem cells (BMSCs) have shown particularly promising results and have been most commonly used. However, the clinical results have yielded only modest results ${ }^{4,8}$. Nevertheless, stem cell therapy for ischemic stroke remains a developing field and as our understanding of stem cell biology grows along with developing biotechnologies, we expect to see improvements in clinical trials ${ }^{8}$. The remainder of this article will focus on reviewing stem cell biology, the intended mechanisms of delivery and action, the results of BMSC therapy in clinical trials for stroke, scientific roadblocks with potential solutions, and promising forthcoming clinical trials.

\section{DISCUSSION}

\section{Stem Cell Application and Biology}

Ischemic strokes in cerebral arteries can occur owing to a variety of mechanisms such as hypoperfusion, embolism, or thrombus formation. These all leave the brain tissue distal to the site of injury deprived of blood, oxygen, and glucose 9 . This deprivation alters cellular homeostasis and elicits multiple processes that can lead to injury or the death of neurons, endothelial cells, and surrounding glial cells ${ }^{9}$. Multiple processes are involved in cell death, such as excitotoxicity, inflammation, apoptosis, and necrosis, each occurring over varying time frames. Excitotoxicity and necrosis can kill cells within minutes of an ischemic event in regions where blood flow is the most restricted 9 . Stem cell transplantation is hypothesized to be able to address these effects of ischemia by promoting neurogenesis, angiogenesis, and neural plasticity to repair the ischemic penumbra, thereby relieving the burden of disability caused by stroke ${ }^{4}$. Neurogenesis is defined as the process of producing new functioning neurons; angiogenesis is defined as the development of new vessels from preexisting vessels. Figure 1 shows that a potential strategy of stem cell transplantation is to magnify the endogenous neurogenesis and angiogenesis triggered after ischemic stroke 6 . These are critical mechanisms that need to be investigated further, as it has been shown that an increase in endogenous brain structural plasticity and angiogenesis has improved recovery and outcomes for patients with ischemic stroke $4,6,10$. Understanding the interaction between transplanted stem cells and the local niche microenvironment is crucial to further our understanding of the efficacy of stem cell transplantation. The local microenvironment influences the effects of stem cells as it is responsible for the viability and metabolic state, communication and feedback, and interlineage coordination of the transplanted stem cells ${ }^{11}$. Understanding this interaction better on a mechanistic level may help bridge the gap between the successes seen in preclinical experiments and the modest results seen in completed 
clinical trials (Table I and Table II) ${ }^{8}$. While numerous approaches have been taken, most stem cell transplantations used in clinical trials have been derived from bone marrow and specifically mesenchymal stem cells (MSCs) for autologous transplantation ${ }^{6}$. MSCs have emerged as a promising option not only because they have a favorable ethical and legal profile, but also because of their safety, lack of immunogenicity, and numerous sources of supply ${ }^{4}$. MSCs are a heterogeneous population of stromal cells isolate from both hematogenous bone marrow and tissues derived from mesoderm such as adipose tissue, pancreas, liver, dermis, synovial membranes, trabecular bone, umbilical cord, lung tissue and pleural cavity, spleen, thymus, peritoneal cavity, lymph node, and deciduous teeth and gingivae ${ }^{4}$. MSCs can be derived from a variety of sources, yet they seem to be phenotypically similar with a small degree of variability in immunomodulation of T-cell proliferation ${ }^{4}$. While it has been observed that these cells show relatively low survival when intracranially injected, bone marrow MSCs have not initiated T-cell priming or humoral antibody production; this is a critical feature for the safety and foundation of forthcoming trials 4,6 . However, MSCs have generated considerable excitement and promise as they have also demonstrated the ability to self-renew, capacity for multipotency, and potential to differentiate into mesodermal, endodermal, and ectodermal cells, including neuronal lineages 4,7. MSCs have also been genetically modified to express growth factors associated with differentiation and survival of host neurons, such as brainderived neurotrophic factor (BDNF), glial cell-derived neurotrophic factor (GDNF), and vascular endothelial growth factor (VEGF), all of which improved functional outcome in preclinical animal models ${ }^{4}$. Additionally, the use of MSCs for transplantation therapy is not unprecedented as MSCs have been used in clinical trials for other pathologies such as for cardiac ischemia, type 2 diabetes, osteoarthritis, liver disease, and spinal cord injury ${ }^{12}$. Further investigations of the mechanisms of action could lead to improvements in forthcoming clinical trials.

\section{Mechanisms of Delivery}

A major factor to consider when designing a clinical trial for stem cell therapy is the method of delivery. Neither preclinical nor clinical trials have determined an optimal method, making this a topic for further investigation. Current methods for BMSC transplantation include intracranial, intra-arterial (IA), and intravenous (IV) infusion ${ }^{6}$. Intracranial cell transplantation involves a stereotactic approach that directly targets the delivery of cells to the damaged lesion ${ }^{10}$. This method results in more transplanted BMSCs to the lesion compared with intravascular injection ${ }^{13}$. However, direct cerebral injection is considered invasive and results in disruption of healthy cells ${ }^{6}$. In one clinical trial, procedural complications, including a seizure and subdural hematoma, were reported in 3 of 14 patients ${ }^{14}$. Intravascular infusion, which includes IV and IA infusion, has emerged as a viable alternative because it is more feasible and less invasive ${ }^{6}$. In one clinical trial, 5 patients with chronic stroke treated 
with BMSC via IV infusion did not report any adverse effects in both the shortand long-term ${ }^{6}$. The study supports preclinical trial evidence that IV infusion of BMSCs is safe and feasible ${ }^{6}$. IV infusion also allows cells to circulate and distribute throughout the system. As a result, research suggests this method is more effective at responding to global cerebral ischemia because transplanted stem cells are able to circulate throughout the cerebral vasculature. However, this systemic approach also results in cells trapped in the lungs, liver, and spleen, limiting the potential of stem cell migration to the brain ${ }^{6}$.

In contrast, IA infusion allows cells to bypass the peripheral filtering organs and directly infuse the ischemic brain tissue. Studies show that compared with IV infusion, this method results in higher rates of cell engraftment and concentration in the ischemic brain lesion. Despite these advantages, IA infusion is considered more invasive, as preclinical animal trials resulted in higher mortality rates owing to cerebral flow reduction and microvascular occlusion ${ }^{15}$. In summary, the optimal route of stem cell delivery is still a topic of discussion. Studies demonstrate that all methods of delivery result in some form of functional recovery, but the mechanisms remain unknown ${ }^{6}$. We will likely determine an optimal route of delivery once we better understand the mechanisms of action, therapeutic time window, optimal dose, and type of cells.

\section{Mechanisms of Action}

BMSCs have the potential to stimulate neurogenesis, angiogenesis, and synaptic plasticity. Following cerebral ischemia, transplanted BMSCs migrate to damaged lesions, secrete cytokines and growth factors, express neurotrophic factors, recruit endogenous progenitor cells, reduce inflammation, and inhibit apoptosis. Together, these mechanisms suggest BMSC transplantation is a promising treatment for ischemic stroke 6. Here we discuss various mechanisms of action:

\section{(1) BMSC Recruitment to the Ischemic Region}

The migration and "homing" ability of transplanted BMSCs towards the target tissue involves various chemokines, cytokines, and integrins that are released following cerebral infarction. These factors include stromal-derivedfactor-1alpha (SDF-1 $\alpha$ ), chemokine receptor type 4 (CXCR 4$)$, monocyte chemoattractant protein-1 (MCP-1), and selectins ${ }^{16}$. SDF-1 $\alpha$ is a chemokine peptide that acts as a chemoattractant to guide the migration of cells. In the onset of a stroke, SDF-1 $\alpha \mathrm{mRNA}$ and protein are predominantly expressed and localized in the ischemic region, reaching peak expression by 3 to 7 days. CXCR-4, the receptor of SDF-1 $\alpha$, is upregulated and expressed on the surface of BMSCs following transplantation ${ }^{16}$. Studies show that BMSC migration to the infarction site is remarkably decreased if CXCR-4 or SDF-1 $\alpha$, its agonist, is deficient ${ }^{16}$. MCP-1 is another chemoattractant that guides BMSCs to the ischemic region. Studies show that MCP-1 is elevated post-BMSC 
transplantation and is required for the migration mechanism. Neutralizing MCP-1 by incubating ischemic brain tissue with MCP-1 antibody resulted in reduced chemotaxis of BMSCs ${ }^{17}$. Selectins are cell-adhesion molecules that are also known to enhance recruitment of BMSCs. Following ischemic stroke, cerebral vascular endothelium uses selectins to recruit BMSCs to the infarct site. Administration of BMSCs that were deficient of CD-44, an E-selectin ligand, resulted in poor recruitment of BMSCs ${ }^{18}$.

(2) BMSC Transplantation Increases Neurotrophic Factors

BMSCs stimulate a variety of growth factors that establish a local niche microenvironment conducive to the facilitation of neurorestorative processes at the infarct site. These include BDNF, GDNF, basic fibroblast growth factor, insulin-like growth factor-1, hepatocyte growth factor, VEGF, angiogenic factor, and stem cell factor. Together, these factors induce neurogenesis, angiogenesis, synaptic and axonal regeneration, differentiation of endogenous progenitor cells, and reduction of apoptosis in the ischemic site ${ }^{4}$. BMSCs also upregulate bone morphogenetic protein-2 and 4 (BMP-2/4), which is known to increase astrocyte differentiation and elevate expression of gap junctional protein connexin-43 (CX-43), which in turn facilitates the exchange of small molecules in the brain to enhance synapse efficacy. Studies that cocultured ischemic astrocytes with BMSCs showed elevated BMP-2/4 protein, which suggests they may play a role in functional recovery after stroke ${ }^{19}$.

(3) BMSC Transplantation Promotes Angiogenesis and Cerebral Circulation

BMSC transplantation stimulates growth factors to enhance angiogenesis and mitigate the breakdown of vessels following an ischemic stroke. Studies show that IV infusion of BMSCs after stroke increases vascularization at the infarct site by increasing expression of angiogenic factors such as VEGF, angiopoietin-1, and erythropoietin 4 . Furthermore, BMSCs interact with blood vessels to form a supportive environment to promote neurogenesis. A recent investigation discovered that BMSCs rescued injured endothelial cells by inducing mitochondrial transfer via tunneling nanotube-like structures 20 . Overall, angiogenesis stimulates blood flow and metabolism, and it regenerates blood vessels in the damaged lesion, which is essential for neural repair ${ }^{4}$.

(4) BMSCs Can Suppress Apoptosis and Inflammation

BMSCs effectively inhibit apoptosis in the infarct site following ischemic stroke ${ }^{6}$. Rat models treated with BMSCs showed a reduction in density of apoptotic cells ${ }^{4}$. BMSCs also inhibit caspase-3, reduce $\mathrm{Bax} / \mathrm{Bcl}-2$ ratio ${ }^{10}$, and decrease interleukin (IL)-1 $\beta$, IL-6, and tumor necrosis factor- $\alpha$ levels ${ }^{4}$, known regulators of apoptosis. BMSCs also function as an immunomodulator to reduce inflammation after ischemic stroke. After BMSC transplantation, many inflammatory and immune response genes are downregulated ${ }^{6}$. BMSCs reduce T-cell proliferation, decrease proinflammatory cytokine levels, and 
downregulate B cells, natural killer cells, and antigen-presenting cells. In addition, BMSCs secrete a variety of growth factors that recruit protective regulatory $\mathrm{T}$ cells ${ }^{21}$. Together, these results indicate that BMSCs play an important role in immunomodulation.

\section{(5) BMSCs Facilitate Proliferation in Endogenous Neurogenesis}

BMSCs may contribute to functional recovery after ischemic stroke by facilitating proliferation in endogenous progenitor cells. Rat models treated with BMSCs saw elevated levels of oligodendrocyte precursor cells that paralleled enhanced white matter areas ${ }^{6}$. One study showed that rat models treated with BMSCs had a higher rate of endogenous neural stem cell proliferation at the infarct site compared with the control group. While the exact mechanism is still unknown, mounting evidence suggests that cytokines and trophic factors, such as BDNF, VEGF, and nerve growth factor, stimulated by BMSCs contribute to the favorable microenvironment for endogenous neurogenesis 22 .

(6) BMSCs Encourage Axonal Sprouting, Myelin Remodeling, and Restoration of Neural Circuits

BMSCs encourage axonal sprouting, myelin remodeling, and regeneration of existing neural circuits, which may contribute to neurologic functional recovery after ischemic stroke ${ }^{6}$. Following IV administration of BMSCs, a significant increase in white matter bundles, axons, and myelin sheaths was detected at the ischemic site and the corpus callosum of rats. This study suggests BMSCs may also induce neurons to restore connections between different cerebral areas 4,6 . One recent study investigated the functional integrity and electrophysiology of neuronal circuits after BMSC transplantation. The study provided substantial evidence that BMSC transplantation has the potential to repair neural networks and restore lost neuronal connections ${ }^{6}$.

\section{(7) BMSCs Differentiate Into Neurons and Astrocytes}

While the previously discussed mechanisms involve the ability of BMSCs to support and enhance endogenous mechanisms, BMSCs also have the potential to integrate into host tissue ${ }^{6}$. Studies that tracked transplanted GFP-labeled BMSCs identified a small proportion of these cells that expressed neuronal or glial protein markers. One study that stereotactically monitored transplanted BMSCs showed that $1 \%$ expressed neuronal marker NeuN and $8 \%$ expressed glial fibrillary acidic protein ${ }^{23}$. Intravascular transplantation of BMSCs also yielded similar results. However, these findings could not conclusively determine whether BMSCs directly differentiated into neural cells or if they fused with persistent neural cells ${ }^{6}$. Therefore, BMSC differentiation into neural cells will require further investigation to elucidate the mechanism and determine efficacy. 


\section{Clinical Trial Design and Preliminary Findings}

The past decade has seen a number of clinical trials that have tested the feasibility of cell therapy in patients with ischemic stroke. Along with difficulties in devising proper delivery mechanisms and correcting for biological deviations, challenges in designing trials arise in available patient populations. In adjusting for variables, researchers produce stringent inclusion criteria that take into account patient factors such as age, time from incidence, and measures such as the National Institutes of Health (NIH) Stroke Scale (NIHSS) and the modified Rankin Scale (mRS), both of which relate patient mobility and cognitive function as a function of stroke damage. Upon selection, the same patient population was once again examined with a combination of these scales to test potential changes in health and assess safety and feasibility of transplantation. Further, we previously noted that specimens for transplantation often come from a variety of origins, some of which are heavily contested. For the purposes of this review, we focus solely on lines derived from bone marrow, MSCs, and mononuclear cells (MNCs). Cells underwent cell-sorting using a CD34 marker, with MSCs displaying as negative and MNCs as positive ${ }^{6}$.

Patient populations were selected based on age, with a range of 15 to 80 years (Table II). Patients were further filtered using time since first incidence of stroke. However, this secondary filter varied among studies, with some requiring participation within 7 days of incidence ${ }^{24}$, while others required 3 months to 1 year after incidence ${ }^{25}$. Common among all studies was a disposition to exclude patients with secondary complications such as autoimmune disorders, peripheral bleeding, liver failures, neurological deficits, and unwillingness to participate in the study 25 .

The detailed studies used various tools, such as the NIHSS and mRS scales, to measure neurological and muscular ability as a readout for patient inclusion and outcome. Established by the NIH, the NIHSS describes 11 different categories that test sensation, language, and mobility ${ }^{26}$. In each category, patients are given a score of 0 to 4 , with higher numbers indicating a further deterioration of ability. Similarly, the mRS measures the extent of disability on a scale of 0 to 6 , with higher numbers indicative of severity ${ }^{26}$. The mentioned studies required proof of disability as a direct result of stroke and often measured these in terms of NIHSS scores ranging from 3 to 15, with many indicating 7 as a benchmark. $\mathrm{mRS}$ scores differed between studies but indicated the need for patients with severe disability.

Studies tested 3 different aspects of the pharmaceutical process: safety, feasibility, and efficacy. Phase 1 trials often dealt with safety and feasibility and, if approved for phase 2, trials went on to test efficacy. The major safety concerns that patients were often monitored for among the trials included postintervention stroke, fever, vascular malformation, immune reactions, cognitive alterations, aberrant neuronal connections related to seizures, and 
tumor formation. Two trials did report seizures, a serious adverse event, among BMSC-treated patients but in each case, adverse events did not differ between groups 24,27 . One potential avenue of investigation would be to determine whether the underlying pathology between cohorts is the same or whether the seizures in the BMSC cohort may have resulted from off-target growth of newly developed circuits. Nevertheless, we have noted that all mentioned studies determined their trial to be safe, feasible, or both. In particular, Ghali et al. (2016) noted that, while transplanted cells may not directly repair, they provide the scaffolding on which neural cells may differentiate and work 28 . Additionally, Moniche et al. (2012) found a dose-dependent trend towards improved functional outcome, Banerjee et al. (2014) found a trend towards functional improvement, and Lee et al. (2010) found that functional recovery was more frequent in the MSC group 24,27,29. However, while these results seem promising, they fail to establish statistically significant improvement over the control groups. Higher-stage clinical trials are needed to build on these promising studies and to continue examining the efficacy of BMSC transplantation.

\section{Roadblocks and Future Solutions}

One of the limitations of current stem cell therapies is a limited source of transplantable stem cells ${ }^{8}$. Within the bone marrow, MSCs are approximately 1 in 10,000 cells ${ }^{4}$. This is an issue because, while further research needs to be done to determine the optimal cell dosage and route of administration of stem cells in cardiovascular diseases, it is clear that administration of a sufficient cell dose is mandatory to obtain the beneficial effects of stem cells ${ }^{8}$. Specifically, in regard to autologous transplantations, the number of MSCs in bone marrow has been shown to dramatically decline with age and there is often a loss of stem cell characteristics during culture expansion ${ }^{8}$. The presence of an optimal time window for stem cell therapies also raises issues in terms of treatment. Some studies have shown it is possible that mechanistic targets for cell therapy may differ depending on temporal windows after stroke ${ }^{8}$; this requires further investigation in order to make therapy more effective. Inherited limitations and possible adverse effects are also concerns regarding stem cell therapy ${ }^{8}$.

Figure $2{ }^{8}$ shows potential strategies to address these challenges. Differential sources of stem cells could potentially advance the current state of stem cell therapy. Other

sources of MSCs, such as adipose tissue or umbilical cord MSCs, could possibly be used to address the issue of a decrease in the number and function of BMSCs in elderly patients (Bang et al., 2016). Adipose-derived stem cells (ADSCs) and umbilical cord MSCs improved functional recovery in animal models of stroke even when administered after a delayed time ${ }^{8}$. Whether these results can be translated into clinical studies remains to be investigated. Allogeneic stem cells also show potential as an alternative to autologous stem cells because the time required to obtain a sufficient number of cells would 
be reduced ${ }^{8}$. This would solve the problem of the limited number of transplantable stem cells. However, there is conflicting evidence that the viability of allogeneic MSCs after infusion is greatly reduced compared with autologous MSCs ${ }^{8}$.

Another major concern with stem cell therapy is cell-mediated adverse effects such as tumor formation of transplanted cells that may delay recovery after stroke and trapping of stem cells in the lung (due to IV application) or brain vessels (from IA application), as previously discussed ${ }^{8}$. Several studies reported that intranasal delivery of MSCs improved neurovascular regeneration and functional recovery after stroke. This method of delivery could possibly provide a simple, noninvasive and brain-specific mode for cell therapy as an alternative to previously used methods ${ }^{8}$. Another study demonstrated how granulocyte-colony-stimulating factor (G-CSF) can mobilize BMSCs in patients with subacute ischemic stroke ${ }^{30}$. G-CSF is a growth factor that acts on hematopoietic stem (CD34+) cells to regulate neutrophil progenitor proliferation and differentiation ${ }^{30}$. Preclinical data demonstrated that G-CSF has neuroprotective and neurorestorative properties, and it was shown to not induce platelet aggregation or microembolism in a clinical study ${ }^{30}$, potentially addressing issues associated with IV or IA delivery. Another potential strategy is the IV coadministration of stem cells with mannitol, an osmotic agent that regulates the permeability of the blood-brain barrier (BBB) to allow a greater number of stem cells transplanted at the infarct site ${ }^{8}$. In one preclinical trial, administration of IV mannitol prior to MSC treatment resulted in increased levels of trophic factors in the infarcted brain ${ }^{8}$. Because mannitol is already widely used in clinical practice ${ }^{8}$, it is a viable option for future clinical trials.

Another option to address the issue of delivery in the future would be cell therapy using the secretome (trophic factors, cytokines, or chemokines produced through paracrine secretion) or extracellular vesicles (EVs) (e.g., microvesicles and exosomes) derived from stem cells ${ }^{8}$. This would create a cell-free paradigm that would avoid the issues associated with cells such as tumor formation and infarcts by vascular occlusion ${ }^{8}$. While studies have yet to determine the effects of stem cell-derived EVs in patients with stroke ${ }^{8}$, it is a promising strategy for potential future development and use. New technology could also be leveraged to improve the efficacy of delivery, such as 3-dimensional (3D) bioprocessing techniques ${ }^{8}$. MSCs can be prepared as spheroid-shaped cellular aggregates by simple 3D bioprocessing techniques: these 3D MSC aggregates may have advantages over MSCs from monolayer cultures in terms of therapeutic potential ${ }^{8}$. For instance, secreted antiinflammatory, proangiogenic, and promitotic factors were shown to be highly enriched in 3D MSC aggregates ${ }^{8}$. This strategy can be further developed and improved in the future. 
Improving cell tracking in vivo is another potential strategy to improve the analysis of clinical trial results. In a clinical study by Ghali et al. (2016), one of the stated limitations was not only the small sample size, but also the absence of implanted cell tracking in vivo ${ }^{28}$. One option is to tag cells with nanoparticles (supraparamagnetic iron oxide [SPIO]), which can then be monitored via magnetic resonance imaging (MRI). The issue with this strategy is that MRI cannot assess graft survival because released iron oxide particles from dead cells give the same magnetic resonance signal ${ }^{6}$. Bioluminescence imaging (BLI) overcomes this issue by requiring expression of luciferase reporter gene that is transfected or transduced into cells prior to transplantation. This technique depends on an active enzyme so that theoretically only live cells will be tracked. However, BLI provides only 2-dimensional images with low spatial resolution, and downregulation of luciferase expressions can give a false-negative result 6. Another approach is transplanting cells harboring a positron emission tomography (PET) reporter gene. While the detection threshold of PET is more sensitive than MRI, PET has a low spatial resolution and does not give adequate anatomical information ${ }^{6}$. To offset limitations of each technique, combining MRI, BLI, and PET imaging techniques could be used to harness the benefits of each technique ${ }^{6}$.

In vivo imaging could also be used to monitor the brain response to cell therapy. PET for monitoring metabolic activity, perfusion studies for neovascularization and blood flow, functional MRI for cerebral plasticity, diffusion-tensor imaging for evaluating fiber tract integrity, and MRI tracking of SPIO particles can monitor brain inflammation 6 . These all would serve as surrogate indicators of graft efficacy. As more is understood about the mechanisms of action, in vivo imaging could also be used to predict on a patient-by- patient basis when the brain microenvironment is optimal for cell transplantation. For example, if enhancing vascularization is found to be important for cell-mediated recovery, then it would be optimal to transplant when the angiogenic VEGF receptor is upregulated ${ }^{6}$.

All of the solutions discussed show potential to improve the current state of stem cell therapy for ischemic stroke, but further research is needed to determine the value of these methods. Table III lists the relevant ongoing clinical trials, which involve the use of BMSCs for patients with ischemic stroke. While the methods used are varied, such as method of delivery, cell number, and time of administration, each trial examines motor function as an outcome measure. Despite the variability in methods, these trials will continue to elucidate the efficacy of stem cell transplantation therapy and contribute to the growing literature on the efficacy of BMSC transplantation.

\section{CONCLUSION}

The urgent need for new treatments for patients with ischemic stroke has sparked interest in stem cell therapy as a solution. Preclinical trials have indicated that stem cell therapy for ischemic stroke is effective at a statistically 
significant level in restoring functional outcome. BMSCs, in particular, show promise as an option for stem cell therapy. While many of the clinical trials discussed failed to show statistically significant results in terms of therapeutic benefit of stem cell therapy for patients with ischemic stroke, there is promise for the future. It is also important to note that the clinical trials discussed show that the therapy is safe and feasible; this provides a critical foundation for future trials. Stem cell therapy represents a significant shift in therapeutic strategy away from thrombolytic therapy and towards a regenerative approach to care. Further research is needed to better understand the mechanisms of action in the successful animal models. A greater understanding of stem cell integration and modulation of the microenvironment can not only improve patient care, but can also help guide and optimize stem cell characteristics in future trials.

Advances in our understanding of stem cell biology and biotechnologies, such as engineering and imaging techniques, can lead to more efficacious therapies. These methods include developing imaging techniques for tracking cells in vivo; better understanding the benefits of the interaction of substances, such as mannitol or G- CSF, with stem cells; investigating alternative methods of delivery, such as intranasal delivery; and conducting further research into 3D bioprocessing techniques to increase the efficacy of treatment. As we develop techniques to better engineer cells, we can also better understand how to tailor stem cell therapy to best treat specific patients. As the clinical trials continue to progress to later phases with growing numbers of enrolled patients, we hope to not only learn more about the mechanisms of action of stem cells, but also see improved efficacy of stem cell therapy. 
Table I: Summary of notable preclinical studies performed both in vitro and in vivo using rodent models ${ }^{\mathrm{a}}$

\begin{tabular}{|c|c|c|c|c|c|}
\hline Author & Publication & Stem Cell Type & Model & Goal & Findings \\
\hline Jin & 2005 & $\begin{array}{l}\text { Neural } \\
\text { precursors }\end{array}$ & Rat & $\begin{array}{l}\text { To compare how focal } \\
\text { cerebral ischemia affects } \\
\text { entry, migration, and } \\
\text { phenotypic features of } \\
\text { neural precursor cells } \\
\text { transplanted by different } \\
\text { routes }\end{array}$ & $\begin{array}{l}\text { Enhanced migration of neural } \\
\text { precursor cells in the ischemic } \\
\text { brain was most evident after } \\
\text { intrastriatal transplantation }\end{array}$ \\
\hline Shyu & 2008 & $\begin{array}{l}\text { Hematopoietic } \\
\text { BM-derived } \\
\text { cells }\end{array}$ & Rat & $\begin{array}{l}\text { To analyze the effects of } \\
\text { SDF-1 } \alpha \text { administration } \\
\text { on ischemic rats as a } \\
\text { function of induced } \\
\text { cerebral infarction and } \\
\text { neurological behavior } \\
\text { before/after cerebral } \\
\text { ischemia }\end{array}$ & $\begin{array}{l}\text { Increased neural plasticity and } \\
\text { decreased cerebral infarction } \\
\text { volumes are seen with an } \\
\text { intracerebral SDF-1 } \alpha \\
\text { administration that leads to } \\
\text { increased BM-derived cell } \\
\text { targeting to ischemic brain }\end{array}$ \\
\hline Walczak & 2008 & MSCs & Rat & $\begin{array}{l}\text { To evaluate laser Doppler } \\
\text { flow and magnetic } \\
\text { resonance methods for } \\
\text { noninvasive dual } \\
\text { monitoring of targeted IA } \\
\text { delivery }\end{array}$ & $\begin{array}{l}\text { High levels of IA engraftment } \\
\text { rates associated with impeded } \\
\text { cerebral blood flow, but also } \\
\text { more readily visualized than IV }\end{array}$ \\
\hline Wang & 2002 & MSCs & Rat & $\begin{array}{l}\text { To investigate the } \\
\text { mechanisms targeting } \\
\text { MSC migration into } \\
\text { ischemic brain }\end{array}$ & $\begin{array}{l}\text { Monocyte chemoattractant } \\
\text { protein-1 found elevated in rat } \\
\text { ischemic brain and this may } \\
\text { contribute to MSC migration } \\
\text { into ischemic brain }\end{array}$ \\
\hline Yilmaz & 2011 & BMSCs & Mice & $\begin{array}{l}\text { To determine if selectins } \\
\text { mediate BMSCs into } \\
\text { postischemic cerebral } \\
\text { microvasculature }\end{array}$ & $\begin{array}{l}\text { Selectin needed for BMSC } \\
\text { migration to site of infarct }\end{array}$ \\
\hline Xin & 2006 & BMSCs & $\begin{array}{l}\text { In } \\
\text { vitro }\end{array}$ & $\begin{array}{l}\text { To test whether BMSCs } \\
\text { contribute to } \\
\text { neurological functional } \\
\text { recovery in stroke } \\
\text { through alteration of } \\
\text { astrocytic expression }\end{array}$ & $\begin{array}{l}\text { BMSCs work to increase BMP2/ } \\
4 \text { expression to enhance } \\
\text { gliogenesis from progenitor } \\
\text { subventricular cells }\end{array}$ \\
\hline Liu & 2014 & MSCs & $\begin{array}{l}\text { In } \\
\text { vitro }\end{array}$ & $\begin{array}{l}\text { To investigate tunneling } \\
\text { nanotube mechanisms of } \\
\text { mitochondrial transfer } \\
\text { from MSCs to } \\
\text { endothelial cells, leading } \\
\text { to a rescue of injured } \\
\text { vascular endothelial cells }\end{array}$ & $\begin{array}{l}\text { Stem cells may rescue damaged } \\
\text { vascular endothelial cells } \\
\text { through unknown mechanism; } \\
\text { nanotube formations may be } \\
\text { part of a defense-rescue } \\
\text { mechanism between apoptotic } \\
\text { endothelial cells and stem cells }\end{array}$ \\
\hline $\mathrm{Li}$ & 2000 & $\begin{array}{l}\text { Non- } \\
\text { hematopoietic } \\
\text { bone- marrow } \\
\text { derived cells }\end{array}$ & Mice & $\begin{array}{l}\text { To test whether } \\
\text { transplanted non- } \\
\text { hematopoietic cells into } \\
\text { adult mice stroke } \\
\text { survivors survive, } \\
\text { migrate, and } \\
\text { differentiate to } \\
\text { parenchymal phenotypes }\end{array}$ & $\begin{array}{l}\text { Infarct volumes did not show } \\
\text { significant change, but } \\
\text { transplanted cells survived in } \\
\text { ischemic brain and improved } \\
\text { functional recovery in adult mice }\end{array}$ \\
\hline $\mathrm{Li}$ & 2012 & ADMSCs & Rat & $\begin{array}{l}\text { To test neuroprotective } \\
\text { capabilities of autologous } \\
\text { ADMSC transplantation } \\
\text { in cerebral I/R injury }\end{array}$ & $\begin{array}{l}\text { ADMSC transplantation therapy } \\
\text { protects against I/R injury } \\
\text { through inhibition of neuronal } \\
\text { apoptosis and decreased } \\
\text { caspase- } 3 \text { activity and the Bax/ } \\
\text { Bcl-2 protein ratio }\end{array}$ \\
\hline Krampera & 2006 & $\begin{array}{l}\text { Bone marrow } \\
\text { derived; MSCs }\end{array}$ & $\begin{array}{l}\text { In } \\
\text { vitro }\end{array}$ & $\begin{array}{l}\text { To study how MSCs } \\
\text { inhibit proliferation of } \\
\text { HLA-unrelated T cells }\end{array}$ & $\begin{array}{l}\text { Immunomodulatory properties } \\
\text { of MSCs may be activated by T- } \\
\text { cell-derived IFN-! to suppress T } \\
\text { cells, B cells, and NK cells }\end{array}$ \\
\hline Yoo & 2008 & MSCs & Rat & To study the mechanism & MSCs provide therapeutic \\
\hline
\end{tabular}




\begin{tabular}{llll}
\hline Author $\quad$ Publication & Stem Cell Type $\quad$ Model & Goal & $\begin{array}{l}\text { Findings } \\
\text { effects by dually upregulating } \\
\text { endogenous neurogenesis and } \\
\text { acting as protective agents for } \\
\text { newborn cells }\end{array}$ \\
& $\begin{array}{l}\text { behind potential MSC } \\
\text { involvement in higher } \\
\text { functional recovery }\end{array}$ & \\
\hline
\end{tabular}

${ }^{a}$ These studies provide the foundation and guidance forcurrent and future clinical trials. Abbreviations: ADMSCs, adipose-derived mesenchymal stem cells; BM, bone marrow; BMP, bone morphogenetic protein -2 and 4; BMSCs, bone marrow stem cells; IA, intra-arterial; I/R, ischemia/reperfusion; IV, intravenous; MSCs, mesenchymal stem cells; SDF-1 $\alpha$, stromal-derived-factor-1alpha. 
Table II: Summary of notable completed clinical trials ${ }^{\mathrm{a}}$

\begin{tabular}{|c|c|c|c|c|c|c|c|c|}
\hline \multirow[t]{2}{*}{ Author } & \multirow[t]{2}{*}{$\begin{array}{l}\text { Publication } \\
\text { Year }\end{array}$} & \multirow[t]{2}{*}{$\begin{array}{l}\text { Delivery } \\
\text { Method }\end{array}$} & \multirow[t]{2}{*}{ Cell Type } & \multirow[t]{2}{*}{$n$} & \multirow[t]{2}{*}{ Purpose } & \multirow[t]{2}{*}{ Conclusion } & \multicolumn{2}{|c|}{$\begin{array}{l}\text { Inclusion } \\
\text { Criteria }\end{array}$} \\
\hline & & & & & & & $\begin{array}{l}\text { NIHSS } \\
\text { Score }\end{array}$ & $\begin{array}{l}\text { Modified } \\
\text { Ranking } \\
\text { Scale } \\
\text { Score }\end{array}$ \\
\hline Sprigg & 2006 & N/A & $\begin{array}{l}\text { CD34+ stem } \\
\text { cells }\end{array}$ & 36 & $\begin{array}{l}\text { Test safety and } \\
\text { ability of G- } \\
\text { CSF to } \\
\text { mobilize CD3 } \\
\text { 4+ stem cells }\end{array}$ & $\begin{array}{l}\text { Safe; well } \\
\text { tolerated; } \\
\text { CD34+ stem } \\
\text { cell levels } \\
\text { elevated }\end{array}$ & N/A & $\begin{array}{l}\text { Median: } \\
4\end{array}$ \\
\hline Lee & 2010 & IV & Mesenchymal & 85 & $\begin{array}{l}\text { Evaluate long- } \\
\text { term safety } \\
\text { and efficacy of } \\
\text { MSCs }\end{array}$ & $\begin{array}{l}\text { IV autologous } \\
\text { MSC } \\
\text { transplantation } \\
\text { safe during } \\
\text { long-term } \\
\text { follow-up. May } \\
\text { improve } \\
\text { recovery } \\
\text { depending on } \\
\text { patient } \\
\text { characteristics }\end{array}$ & $\geq 7$ & N/A \\
\hline Bhasin & 2011 & IV & Mesenchymal & 40 & $\begin{array}{l}\text { Feasibility and } \\
\text { efficacy by } \\
\text { scoring and } \\
\text { functional } \\
\text { imaging }\end{array}$ & $\begin{array}{l}\text { Safe and } \\
\text { feasible }\end{array}$ & $4-15$ & N/A \\
\hline Bhasin & 2012 & IV & $\begin{array}{l}\text { Mononuclear } \\
\text { and } \\
\text { Mesenchymal }\end{array}$ & 12 & $\begin{array}{l}\text { Study safety, } \\
\text { feasibility, and } \\
\text { efficacy of } \\
\text { autologous } \\
\text { transplantation }\end{array}$ & $\begin{array}{l}\text { Safe and } \\
\text { feasible; cells } \\
\text { may aid in } \\
\text { stroke repair } \\
\text { mechanisms }\end{array}$ & $4-15$ & N/A \\
\hline Moniche & 2012 & IA & Mononuclear & 20 & $\begin{array}{l}\text { Safety, efficacy, } \\
\text { and biologic } \\
\text { effects of BM- } \\
\text { MSC } \\
\text { transplantation }\end{array}$ & $\begin{array}{l}\text { Efficacy could } \\
\text { not be } \\
\text { concluded; } \\
\text { safe and } \\
\text { feasible }\end{array}$ & $\geq 8$ & N/A \\
\hline Banerjee & 2013 & IA & Mononuclear & 5 & $\begin{array}{l}\text { Safety; } \\
\text { promotion of } \\
\text { angio-/neuro- } \\
\text { genesis }\end{array}$ & $\begin{array}{l}\text { Safe and } \\
\text { feasible }\end{array}$ & $\geq 8$ & N/A \\
\hline Prasad & 2014 & IV & Mononuclear & 58 & $\begin{array}{l}\text { Safety; } \\
\text { assessment by } \\
\text { Rankin score }\end{array}$ & $\begin{array}{l}\text { No statistical } \\
\text { difference in } \\
\text { scores }\end{array}$ & $\geq 7$ & N/A \\
\hline Ghali & 2016 & IA & Mononuclear & 39 & $\begin{array}{l}\text { Preclinical to } \\
\text { clinical } \\
\text { transition } \\
\text { study }\end{array}$ & $\begin{array}{l}\text { No significant } \\
\text { improvement } \\
\text { between study } \\
\text { control groups; } \\
\text { no adverse } \\
\text { reactions }\end{array}$ & $10-12$ & $>2$ \\
\hline
\end{tabular}

${ }^{a}$ The clinical trials mainly demonstrate the safety and feasibility of transplantation, but do not show statistically significant results in terms of therapeutic benefits. Abbreviations: BM, bone marrow; G-CSF, granulocyte-colony-stimulating factor; IA, intra-arterial; IV, intravenous; MSCs, mesenchymal stem cells; N/A, not available; NIHSS, National Institutes of Health Stroke Scale. 
Table III: Ongoing Clinical Trials of Bone-Marrow-Derived Stem Cell Transplantation Therapy for Ischemic Stroke ${ }^{\mathrm{a}}$

\begin{tabular}{|c|c|c|c|c|c|c|c|}
\hline Trial ID & Status & Start Date & End Date & Phase & $\begin{array}{l}\text { Patients } \\
\text { Enrolled }\end{array}$ & Delivery & $\begin{array}{l}\text { Outcome } \\
\text { Measures }\end{array}$ \\
\hline NCT02564328 & Recruiting & $\begin{array}{l}\text { November } \\
2014\end{array}$ & $\begin{array}{l}\text { November } \\
2017\end{array}$ & 1 & 40 & IV & $\begin{array}{l}\text { FMMS NIHSS } \\
\text { Barthel Index } \\
\text { mRS Visual \& } \\
\text { brain } \\
\text { examination }\end{array}$ \\
\hline NCT01468064 & Recruiting & $\begin{array}{l}\text { November } \\
2011\end{array}$ & $\begin{array}{l}\text { March } \\
2017\end{array}$ & 1,2 & 20 & IV & $\begin{array}{l}\text { Adverse } \\
\text { events } \\
\text { Barthel index } \\
\text { mRS }\end{array}$ \\
\hline NCT02448641 & Recruiting & $\begin{array}{l}\text { January } \\
2016\end{array}$ & $\begin{array}{l}\text { September } \\
2017\end{array}$ & 2 & 156 & $\begin{array}{l}\text { Stereotactic } \\
\text { intracranial } \\
\text { injection }\end{array}$ & $\begin{array}{l}\text { FMMS mRS } \\
\text { ARAT Gait } \\
\text { velocity } \\
\text { Upper } \\
\text { extremity } \\
\text { function } \\
\text { Lower } \\
\text { extremity } \\
\text { function }\end{array}$ \\
\hline NCT01922908 & $\begin{array}{l}\text { Not yet } \\
\text { recruiting }\end{array}$ & $\begin{array}{l}\text { December } \\
2016\end{array}$ & $\begin{array}{l}\text { December } \\
2018\end{array}$ & 1,2 & 48 & IV & $\begin{array}{l}\text { Maximum } \\
\text { tolerated } \\
\text { dose } \\
\text { Improved } \\
\text { functional } \\
\text { outcome }\end{array}$ \\
\hline
\end{tabular}

aThe relevant trials were listed on http://clinicaltrials.gov and found by searching "ischemic stroke AND stem cells." Abbreviations: ARAT, ; FMMS, ; IV, intravenous; mRS, modified Rankin Scale; NIHSS, National Institutes of Health Stroke Scale.

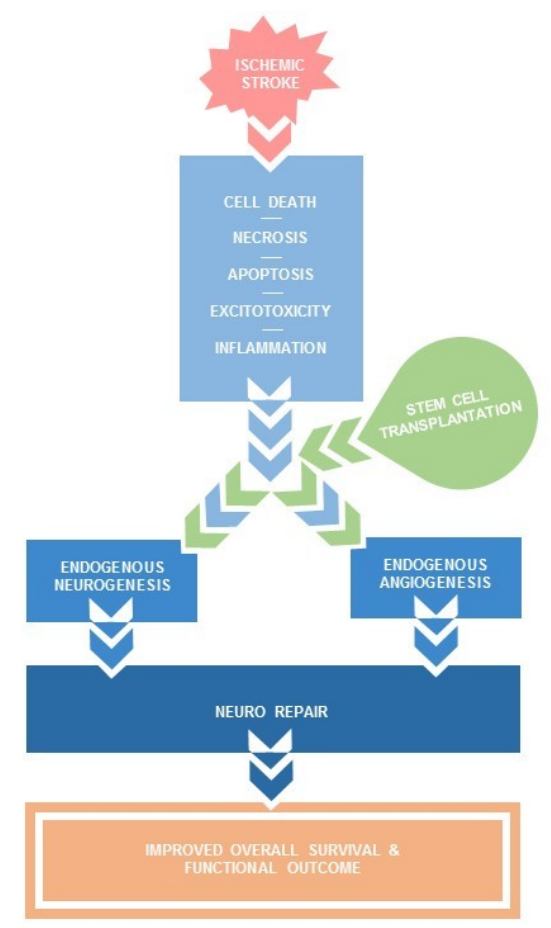

Figure 1: Stem cell transplantation is thought to augment endogenous repair mechanisms by contributing to neurogenesis and angiogenesis via microenvironment interactions such as immune modulation, paracrine signaling, neurotrophic factor secretion, andremodeling of synaptic plasticity. Mesenchymal stem cell differentiation remains a topic of investigation for addressing damaged neural tissue and functional recovery as its efficacy remains inconclusive. 
Challenges/Hurdles

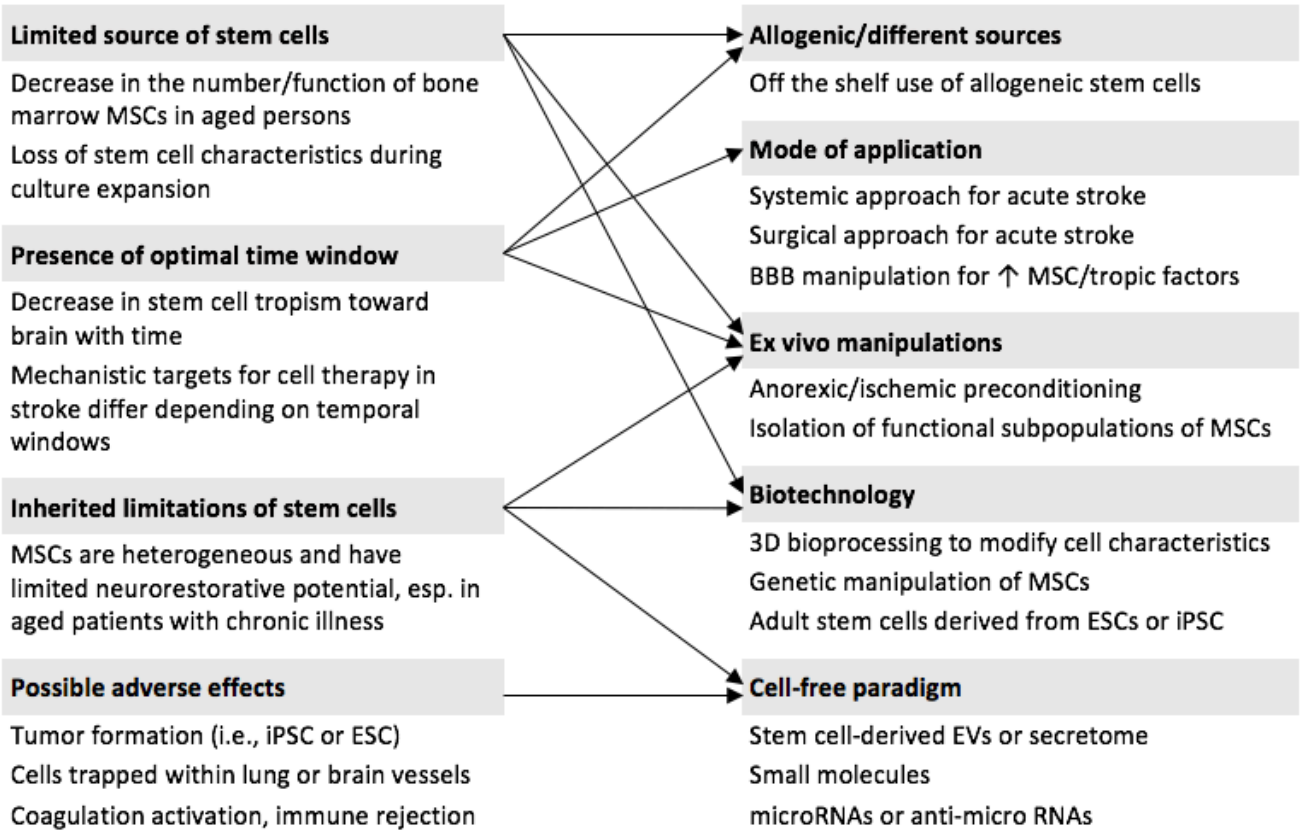

Figure 2: Hurdles of current stem cell therapy and strategies to overcome the challenges. BBB indicates blood-brain barrier; ESC, embryonic stem cells; EV, extracellular vesicle; iPSC, induced pluripotent stem cells; MSC, mesenchymal stem cell. Adapted from Bang et al., 2016. 


\section{REFERENCES}

1. Go AS, Mozaffarian D, Roger VL, et al. Executive Summary: Heart Disease and Stroke Statistics-2014 Update. Circulation. 2014;129(3):399-410. doi:10.1161/

$\underline{01 . c i r .0000442015 .53336 .12}$

2. Mozaffarian D, Benjamin EJ, Go AS, et al. Heart Disease and Stroke Statistics-2015 Update. Circulation. 2015;131(4). doi:10.1161/cir.0000000000000152

3. Ahmed N. Results of Intravenous Thrombolysis Within 4.5 to 6 Hours and Updated Results Within 3 to 4.5 Hours of Onset of Acute Ischemic Stroke Recorded in the Safe Implementation of Treatment in Stroke International Stroke Thrombolysis Register (SITS-ISTR). JAMA Neurol. 2013;70(7):837. doi:10.1001/jamaneurol.2013.406

4. Dulamea AO. The potential use of mesenchymal stem cells in stroke therapy-From bench to bedside. Journal of the Neurological Sciences. 2015;352(1-2):1-11. doi:10.1016/j.jns.2015.03.014

5. Tissue Plasminogen Activator for Acute Ischemic Stroke. N Engl J Med. 1995;333(24):1581-1588. doi:10.1056/nejm199512143332401

6. Bliss TM, Andres RH, Steinberg GK. Optimizing the success of cell transplantation therapy for stroke. Neurobiology of Disease. 2010;37(2):275-283. doi:10.1016/j.nbd.2009.10.003

7. Yoon DS, Choi Y, Jang Y, et al. SIRT1 Directly Regulates SOX2 to Maintain Self-Renewal and Multipotency in Bone Marrow-Derived Mesenchymal Stem Cells. Stem Cells.

2014;32(12):3219-3231. doi:10.1002/stem.1811

8. Bang OY, Kim EH, Cha JM, Moon GJ. Adult Stem Cell Therapy for Stroke: Challenges and Progress. J Stroke. 2016;18(3):256-266. doi:10.5853/jos.2016.01263

9. Doyle KP, Simon RP, Stenzel-Poore MP. Mechanisms of ischemic brain damage. Neuropharmacology. 2008;55(3):310-318. doi:10.1016/j.neuropharm.2008.01.005

10. Li J, Chen Y, Zhang X, Zhang B, Zhang M, Xu Y. Human Urinary Kallidinogenase Improves Outcome of Stroke Patients by Shortening Mean Transit Time of Perfusion Magnetic Resonance Imaging. Journal of Stroke and Cerebrovascular Diseases. 2015;24(8):1730-1737. doi:10.1016/ j.jstrokecerebrovasdis.2015.03.032

11. Lauder, et al. 2012.

12. http://clinicaltrials.gov.

13. Jin K, Sun Y, Xie L, et al. Comparison of ischemia-directed migration of neural precursor cells after intrastriatal, intraventricular, or intravenous transplantation in the rat. Neurobiology of Disease. 2005;18(2):366-374. doi:10.1016/j.nbd.2004.10.010

14. Kondziolka D, Steinberg GK, Wechsler L, et al. Neurotransplantation for patients with subcortical motor stroke: a Phase 2 randomized trial. Journal of Neurosurgery. 2005;103(1):38-45. doi:10.3171/jns.2005.103.1.0038

15. Walczak P, Zhang J, Gilad AA, et al. Dual-Modality Monitoring of Targeted Intraarterial Delivery of Mesenchymal Stem Cells After Transient Ischemia. Stroke. 2008;39(5):1569-1574. doi:10.1161/strokeaha.107.502047

16. Shyu W-C, Lin S-Z, Yen P-S, et al. Stromal Cell-Derived Factor-1 Promotes Neuroprotection, Angiogenesis, and Mobilization/Homing of Bone Marrow-Derived Cells in Stroke Rats. Journal of Pharmacology and Experimental Therapeutics. 2007;324(2):834-849. doi:10.1124/jpet.107.127746 
17. Wang L, Li Y, Chen J, et al. Ischemic cerebral tissue and MCP-1 enhance rat bone marrow stromal cell migration in interface culture. Experimental Hematology. 2002;30(7):831-836. doi:10.1016/s0301-472x(02)00829-9

18. Yilmaz G, Vital S, Yilmaz CE, Stokes KY, Alexander JS, Granger DN. Selectin-Mediated Recruitment of Bone Marrow Stromal Cells in the Postischemic Cerebral Microvasculature. Stroke. 2011;42(3):806-811. doi:10.1161/strokeaha.110.597088

19. Xin H, Li Y, Chen X, Chopp M. Bone marrow stromal cells induce BMP2/4 production in oxygen-glucose-deprived astrocytes, which promotes an astrocytic phenotype in adult subventricular progenitor cells. J Neurosci Res. 2006;83(8):1485-1493. doi:10.1002/jnr.20834

20. Liu K, Ji K, Guo L, et al. Mesenchymal stem cells rescue injured endothelial cells in an in vitro ischemia-reperfusion model via tunneling nanotube like structure-mediated mitochondrial transfer. Microvascular Research. 2014;92:10-18. doi:10.1016/j.mvr.2014.01.008

21. Krampera M, Cosmi L, Angeli R, et al. Role for Interferon- $\gamma$ in the Immunomodulatory Activity of Human Bone Marrow Mesenchymal Stem Cells. Stem Cells. 2006;24(2):386-398. doi:10.1634/stemcells.2005-0008

22. Yoo S-W, Kim S-S, Lee S-Y, et al. Mesenchymal stem cells promote proliferation of endogenous neural stem cells and survival of newborn cells in a rat stroke model. Exp Mol Med. 2008;40(4):387. doi:10.3858/emm.2008.40.4.387

23. Li Y, Chopp M, Chen J, et al. Intrastriatal Transplantation of Bone Marrow Nonhematopoietic Cells Improves Functional Recovery After Stroke in Adult Mice. J Cereb Blood Flow Metab. 2000;20(9):1311-1319. doi:10.1097/00004647-200009000-00006

24. Lee JS, Hong JM, Moon GJ, Lee PH, Ahn YH, Bang OY. A Long-Term Follow-Up Study of Intravenous Autologous Mesenchymal Stem Cell Transplantation in Patients With Ischemic Stroke. STEM CELLS. 2010;28(6):1099-1106. doi:10.1002/stem.430

25. Bhasin, et al. 2012.

26. Prasad K, Sharma A, Garg A, et al. Intravenous Autologous Bone Marrow Mononuclear Stem Cell Therapy for Ischemic Stroke. Stroke. 2014;45(12):3618-3624. doi:10.1161/ $\underline{\text { strokeaha.114.007028 }}$

27. Moniche F, Escudero I, Zapata-Arriaza E, et al. Intra-Arterial Bone Marrow Mononuclear Cells (BM-MNCS) Transplantation in Acute Ischemic Stroke (IBiS Trial): Protocol of a Phase II, Randomized, Dose-Finding, Controlled Multicenter Trial. International Journal of Stroke. 2015;10(7):1149-1152. doi:10.1111/ijs.12520

28. Ghali AA, Yousef MK, Ragab OA, ElZamarany EA. Intra-arterial Infusion of Autologous Bone Marrow Mononuclear Stem Cells in Subacute Ischemic Stroke Patients. Front Neurol. 2016;7. doi:10.3389/fneur.2016.00228

29. Banerjee S, Bentley P, Hamady M, et al. Intra-Arterial Immunoselected CD34+ Stem Cells for Acute Ischemic Stroke. STEM CELLS Translational Medicine. 2014;3(11):1322-1330. doi: $10.5966 / \mathrm{sctm} .2013-0178$

30. Sprigg N, Bath PM, Zhao L, et al. Granulocyte-colony-stimulating factor mobilizes bone marrow stem cells in patients with subacute ischemic stroke: the Stem cell Trial of recovery EnhanceMent after Stroke. Stroke. 2006;37(12). doi:10.1161/01.STR.0000248763.49831.c3 